\title{
Efektivitas Penggunaan Google Classroom pada Masa Pandemi Covid-19 terhadap Hasil Belajar Pendidikan Kewarganegaraan
}

\author{
Usman $\mathbf{M}^{1}{ }^{1}$ Rosmini ${ }^{2}$, Hartati ${ }^{3}$, Singgih Subiyantoro ${ }^{4}$ \\ Universitas Muhammadiyah Sidenreng Rappang ${ }^{1,2,3}$ \\ Universitas Veteran Bangun Nusantara ${ }^{4}$ \\ Email: stkipusman@gmail.com ${ }^{1}$,krosminisaid78@gmail.com ${ }^{2}$. \\ hartatiums98@gmail.com ${ }^{3}$,singgihsubiyantoro@univetbantara.ac.id ${ }^{4}$
}

Riwayat artikel: submit: 5 September 2021 ; revisi: 25 September 2021, diterima: 30 September 2021

\begin{abstract}
ABSTRAK
Tujuan penelitian ini untuk mengetahui efektivitas penggunaan Google Classroom terhadap hasil belajar PKn siswa kelas XI IPA SMA Muhammadiyah Pangsid tahun pelajaran 2021. Penelitian ini terdiri dari dua variabel yaitu penggunaan media pembelajaran Google Classroom dan hasil belajar pada mata pelajaran PKn.Penelitian ini adalah penelitian kuantitatif dengan menggunakan metode preexperimental. Populasi pada penelitian ini adalah seluruh siswa kelas XI IPA SMA Muhammadiyah Pangsid yang berjumlah 13 orang siswa. Sampel ditarik secara keseluruhan atau menggunakan sampel jenuh. Pengujian dilakukan menggunakan tes uraian sebanyak 10 nomor. Teknik pengumpulan data dilakukan dengan teknik tes, dokumentasi dan kuesioner. Berdasarkan hasil analisis data penelitian menunjukkan bahwa nilai rata-rata posttest lebih tinggi yaitu 80 sedangkan hasil pretest yaitu 60, adapun hasil persentase keseluruhan siswa yang memenuhi standar KKM yaitu 92,3\%, atau dari 13 orang siswa, 12 orang yang mendapatkan nilai di atas $70 \mathrm{KKM}$. Indikator efektivitas pada penelitian ini didasarkan pada teori Slavin dalam (Afriliani, 2019). Terdapat empat indikator yang dapat digunakan untuk mengukur keefektifan pembelajaran yaitu; kualitas pembelajaran, tingkat pembelajaran yang sesuai, intensif, dan waktu. Setelah mengumpulkan data, peneliti menganalisa dan menemukan bahwa semua indikator efektivitas telah terlaksana dan dicapai dalam penelitian serta memberikan efek kepada penggunaan Google Classroom terhadap hasil belajar PKn siswa kelas XI IPA SMA Muhammadiyah Pangsid. Berdasarkan hasil analisis data disimpulkan bahwa metode pembelajaran berbasis Google Classroom efektif terhadap hasil belajar siswa. Dengan demikian peneliti menyarankan kepada pihak sekolah hendaknya memberikan dukungan pada penggunaan metode pembelajaran berbasis Google Classroom dalam proses belajar mengajar.
\end{abstract}

Kata kunci: Efektivitas, google classroom, hasil belajar.

\section{ABSTRACT}

The purpose of this study was to determine the effectiveness of the use of Google Classroom on Civics learning outcomes for students of class XI IPA SMA Muhammadiyah Pangsid in the 2021 academic year. This study consisted of two variables, namely the use of Google Classroom learning media and learning outcomes in Civics subjects. using a pre-experimental method. The population in this study were all students of class XI IPA SMA Muhammadiyah Pangsid, totaling 13 students. The sample is drawn as a whole or using a saturated sample. The test was carried out using a description test of 10 numbers. Data collection techniques were carried out by using test, documentation and questionnaire techniques. Based on the results of the analysis of research data, it shows that the posttest average score is 80 , while the pretest results are 60, while the results of the overall percentage of students who meet the KKM standard are $92.3 \%$, or of 13 students, 12 people who get a score above 70 KKM. The effectiveness indicator in this study is based on the theory of Slavin in (Afriliani, 2019). There are four indicators that can be used to measure the effectiveness of learning, namely; quality of learning, appropriate level of learning, intensive, and time. After collecting the data, the researcher analyzed and found that all indicators of effectiveness had been implemented and achieved in the research and had an effect on the use of Google Classroom on the learning outcomes of Civics Class XI IPA SMA 
Usman, M. (2021). Efektivitas Penggunaan Google Classroom pada Masa Pandemi Covid-19 terhadap Hasil Belajar Pendidikan Kewarganegaraan. Edudikara: Jurnal Pendidikan dan Pembelajaran, 6(3), 199210.

Muhammadiyah Pangsid. Based on the results of data analysis, it was concluded that the Google Classroom-based learning method was effective on student learning outcomes. Thus, the researcher suggests that the school should provide support for the use of Google Classroom-based learning methods in the teaching and learning process.

Keywords: Effectiveness, google classroom, learning outcomes

\section{Copyright $\odot 2021$ The Author(s)}

This is an open access article under the CC BY-SA license.

\section{PENDAHULUAN}

Menurut Ki Hajar Dewantara dalam (Sirojuddin, 2020) Pendidikan berarti proses menumbuhkan semua kekuatan alam yang ada pada anak untuk mencapai keselamatan, kebahagiaan manusia dan anggota masyarakat. Berdasarkan (UU RI, NO.20, 2003) tentang Sistem Pendidikan Nasional, menerangkan bahwa pendidikan di Indonesia adalah upaya sadar dan terencana untuk menciptakan suasana belajar dan belajar agar peserta didik dapat secara aktif mengembangkan potensinya untuk memiliki kekuatan spiritual, pengendalian diri, kepribadian, kecerdasan, akhlak mulia dan keterampilan yang dibutuhkan oleh dirinya, masyarakat, bangsa dan negara.

Pembelajaran adalah proses pada pendidik dengan bertujuan memberikan umpan balik, bantuan dan bimbingan kepada siswa tentang pengetahuan pembelajaran profesional. Selanjutnya, interaksi yang baik antara siswa dan pendidik sangat diperlukan dalam pembelajaran. Melalui pembelajaran terencana akan dihasilkan suatu proses, dan penataan proses tersebut mampu menghasilkan ekspektasi dengan baik. Perencanaan studi merupakan proses yang paling penting karena merupakan tempat dimana guru dengan siswa berinteraksi secara langsung, (Dr. Usiono 2017).

Pembelajaran adalah proses komunikasi antara peserta didik, guru dan bahan ajar. Media pembelajaran merupakan alat yang ampuh yang dapat digunakan dalam penyampaian informasi pembelajaran. Sedangkan menurut Gagne, media adalah berbagai komponen lingkungan siswa yang dapat memacu pembelajarannya. Sedangkan menurut Briggs, media merupakan alat fisik untuk bisa menyampaikan informasi dan merangsang siswa untuk belajar Ashar Arsyad dalam (Wicaksono 2018).

Dalam bahasa Arab, media adalah perantara atau penyelenggara pesan dari pengirim ke penerima. Lebih spesifiknya, dalam proses pengajaran, konsep media cenderung diartikan sebagai alat grafik, alat fotografi atau alat elektronik untuk menangkap, mengolah dan merekonstruksi informasi visual atau lisan (Arsyad, 2007: 3) dalam (Aulia 2019).

Numan Soemantri dalam (Andriyani, 2016) pengertian pendidikan yang sesuai untuk Indonesia sebagai program pendidikan yang berinti demokrasi politik yang dilengkapi dengan sumber-sumber ilmu pengetahuan lainnya, Pengaruh positif dari pendidikan sekolah, masyarakat, dan orang tua semuanya diolah untuk melatih siswa berpikir kritis, analitis, dan penuh perhatian, dan Bertindak secara demokratis dalam rangka mempersiapkan kehidupan yang demokratis berdasarkan Pancasila dan UUD 1945. Seorang guru diharapkan mampu untuk bersikap fleksibel dalam mengatasi beragam persoalan dan lebih mengutamakan pendidikan moral serta karakter. Wuryan (2008:9) dalam (Nurgiansah 2019). mengatakan bahwa Pendidikan Pancasila menitikberatkan pada akhlak, sedangkan pendidikan Kewarganegaraan bertujuan membekali siswa dengan pengetahuan dan keterampilan yang mereka butuhkan untuk menjadi warga negara yang bertanggung jawab.

Pengguna e-learning yang biasanya berkembang saat ini menggunakan LMS (Learning Management System). Dalam dunia pendidikan, pembelajaran online sering disebut dengan $e-$ learning yang mengacu pada suatu metode atau konsep pendidikan yang proses 
Usman, M. (2021). Efektivitas Penggunaan Google Classroom pada Masa Pandemi Covid-19 terhadap Hasil Belajar Pendidikan Kewarganegaraan. Edudikara: Jurnal Pendidikan dan Pembelajaran, 6(3), 199210.

pengajarannya memanfaatkan teknologi informasi. Pengertian lain dari e-learning merupakan lingkungan belajar yang dapat digunakan sebagai metode pengajaran tanpa harus bertatap muka antara guru dan siswa agar dapat menggunakan sistem elektronik atau komputer untuk membantu proses pembelajaran (Famukhit 2020).

Seiring perkembangan teknologi informasi dan komunikasi,maka semakin berkembang pula berbagai media pembelajaran yang bisa digunakan dalam proses belajar mengajar maupun dalam proses ujian.Saat ini manusia tidak bisa melakukan aktivitas seperti biasa bahkan sangat dibatasi untuk melakukan kegiatan yang melibatkan orang banyak,hal ini disebabkan oleh Covid-19 yang melanda diseluruh penjuruh dunia dan hal ini mengakibatkan sistem pendidikan sangat mengkhawatirkan khususnya di Indonesia apabila tidak lagi terlaksana. Namun hal tersebut bisa diatasi dengan dengan adanya kebijakan pemerintah untuk tetap melakukan proses belajar mengajar berbasis online. Berdasarkan peraturan Kementrian Pendidikan dan Kebudayaan Nomor 4 Tahun 2020 tentang pelaksanaan kebijakan pendidikan dalam masa darurat penyebaran Corona Virus Disease (Covid-19) seluruh satuan pendidikan memutuskan untuk bekerja dari rumah (Work From Home) (Putri, 2020).

Fajar (2009: 10) dalam (S.Supardi, U 2015) yakin bahwa belajar adalah proses pergantian diri orang yang tampil berupa peningkatan mutu dan jumlah perilaku, layaknya peningkatan pengetahuan, keterampilan, kemampuan berpikir, sikap, kebiasaan, dll.

Sudjana, berpendapat bahwa hasil belajar adalah pengetahuan yang dimiliki siswa setelah memperoleh pengalaman belajar. Selain itu, Munawar, berpendapat bahwa hasil belajar merupakan penilaian akhir berasal dari proses dan pengakuan.

Google Classroom atau Google kelas adalah sebuah platform memadukan pembelajaran dalam lingkup pendidikan memudahkan pengajar untuk membuat, berbagi, dan mengklasifikasikan setiap tugas tanpa kertas (Afrianti 2018).

Menurut situs resmi dari Google dalam (Afrianti 2018), aplikasi Google kelas adalah instrumen efisiensi gratis termasuk email, catatan, dan kapasitas. Tujuan kelas ini adalah untuk mempermudah pendidik menghemat waktu, mengelola kelas, dan meningkatkan korespondensi dengan siswa. Dengan Google kelas, siswa dan pengajar dapat lebih efektif terhubung di dalam dan di luar sekolah. Guru New York Rosemarie DeLoro mengatakan 60 dia tidak pernah menggunakan komputer selama tahun-tahun mengajarnya. Namun, karena ia memiliki Chromebook dan Google kelas, ia dapat dengan mudah memberikan pekerjaan rumah digital kepada siswa dan dapat memberikan masukan waktu nyata kapan pun, di mana pun (Biantoro, 2014) dalam (Afrianti 2018).

Fitur-fitur yang disediakan oleh Google Classroom Assigments (tugas), Grading (pengukuran), Communication (komunikasi), Time-Cost (hemat waktu), Archive course (arsip program), Mobile application (aplikasi dalam telepon genggam), Privacy (privasi). Adapun kelebihan menggunakan Google Classroom menurut Janzen, M 2014 (dalam Iftakhar 2016), mudah digunakan, hemat waktu, berbasis cloud, fleksibel dan gratis. Sedangkan kekurangan yaitu, Google Classroom yang berbasis web mengharuskan pengguna untuk terkoneksi dengan internet, saat Google Drive penuh file tidak bisa terkirim, apabila siswa tidak kritis \& terjadi kesalahan materi akan sangat berdampak pada pengetahuannya, tidak adanya notifikasi dari Google Classroom, dan tidak semua sekolah dapat menggunakan Google Classroom dikarenakan masalah jaringan.

Fajar (2009: 10) dalam (S.Supardi, U 2015) yakin bahwa belajar adalah proses pergantian diri orang yang tampil berupa peningkatan mutu dan jumlah perilaku, layaknya peningkatan pengetahuan, keterampilan, kemampuan berpikir, sikap, kebiasaan, dll. Menurut E. Mulyasa (2003: 82) dalam (Wiguna 2018) menjelaskan efektivitas yaitu bagaimana organisasi berhasil memperoleh dan menggunakan sumber daya untuk mencapai tujuan operasional. Efektivitas biasanya berkaitan erat dengan membandingkan tingkat pencapaian suatu tujuan dengan 
Usman, M. (2021). Efektivitas Penggunaan Google Classroom pada Masa Pandemi Covid-19 terhadap Hasil Belajar Pendidikan Kewarganegaraan. Edudikara: Jurnal Pendidikan dan Pembelajaran, 6(3), 199210.

rencana yang telah ditentukan sebelumnya, atau membandingkan hasil aktual dengan hasil yang direncanakan.

Menurut Slavin dalam (Afriliani, 2019), ada 4 indikator yang dapat digunakan untuk mengukur keefektifan pembelajaran, 4 indikator tersebut antara lain: 1) Kualitas pembelajaran yaitu, mengacu pada kemampuan memberikan informasi atau membantu siswa dalam mempelajari materi pembelajaran dengan mudah, dan kualitas pembelajaran dapat dilihat pada proses pembelajaran dan hasil belajar. 2) Tingkat pembelajaran yang sesuai, artinya guru dapat memastikan bahwa siswa siap untuk mempelajari materi baru. 3) Tindakan insentif adalah kegiatan yang dilakukan oleh guru. Guru harus memastikan bahwa siswa termotivasi untuk mempelajari materi yang diberikan, dan pendidik juga harus memotivasi siswa untuk mengerjakan pekerjaan tugas yang diberikan. 4) Waktu adalah sejauh mana siswa memiliki cukup waktu untuk mempelajari materi. Pembelajaran dapat dikatakan efektif, terutama siswa dapat menyelesaikan pembelajaran sesuai dengan alokasi waktu yang telah dijadwalkan.

Dari pendapat beberapa ahli dapat disimpulkan bahwa efektivitas merupakan ketercapaian tujuan yang telah direncanakan atau ditetapkan dengan hasil yang dicapai.

\section{METODE}

Penelitian ini adalah penelitian kuantitatif menggunakan metode penelitian dengan preeksperimental. Kelompok penelitian menerima perlakuan media pembelajaran berbasis Classroom, dan hanya menyelesaikan tes awal (pre-test) dan tes akhir (post-tes). Sugiyono, 2016 : 35) metode kuantitatif ini disebut sebagai metode positivistik karena berlandaskan pada filsafat positivisme serta data penelitian berupa angka-angka dan analisis menggunakan statistik.

Tabel 1 Desain Penelitian

\begin{tabular}{ccc}
\hline Pretest & Perlakuan & Postest \\
$\mathrm{O}_{1}$ & $\mathrm{X}$ & $\mathrm{O}_{2}$ \\
\hline
\end{tabular}

Dimana:

$\mathrm{O}_{1}=$ Sebelum diberikan perlakuan

$\mathrm{X}=$ Perlakuan

$\mathrm{O}_{2}=$ Setelah diberikan perlakuan

Populasi adalah wilayah generalisasi yang terdiri atas objek atau subjek yang mempunyai kuantitas dan karakteristik teretntu yang ditetapkan oleh peneliti untuk dipelajari dan kemudian ditarik kesimpulannya (Sugiyono, 2016:148).

Adapun populasi dari penelitaian ini adalah seluruh siswa kelas XI IPA SMA Muhammadiyah Pangsid tahun ajaran 2020/2021.

Tabel 2 Populasi Penelitian

\begin{tabular}{ccc}
\hline No. & Kelas & Populasi \\
1. & XI IPA & 13 \\
Jumlah & & 13 \\
\hline
\end{tabular}

Sumber: SMA Muhammadiyah Pangsid

Sampel adalah bagian dari jumlah dan karakteristik yang dimiliki oleh populasi tersebut, (Sugiyono, 2016:149). Sampling jenuh adalah teknik pengambilan sampel di mana seluruh 
Usman, M. (2021). Efektivitas Penggunaan Google Classroom pada Masa Pandemi Covid-19 terhadap Hasil Belajar Pendidikan Kewarganegaraan. Edudikara: Jurnal Pendidikan dan Pembelajaran, 6(3), 199210.

populasi digunakan sebagai sampel. Hal ini sering dilakukan bila populasinya kecil, kurang dari 30 orang.

Tabel 3 Sampel Penelitian

\begin{tabular}{ccccc}
\hline No. & Kelas & Laki-laki & Perempuan & Jumlah \\
1. & XI IPA & 5 & 8 & 13 \\
& & Jumlah & & 13 \\
\hline
\end{tabular}

Sumber: SMA Muhammadiyah Pangsid

Instrumen yang digunakan untuk mengumpulkan data adalah peneliti memberikan tes kepada siswa. Tes digunakan untuk mendapatkan data objektif tentang keefektifan Google Classroom dalam pembelajaran PKn. Dua tes digunakan dalam penelitian ini, yaitu pre-test dan post-test. Pre-test diberikan sebelum pembelajaran sedangkan post-test dilakukan setelah proses belajar mengajar. Tes yang digunakan adalah tes uraian yang berjumlah 10 nomor dan masing-masing diberi bobot sesuai tingkat kesulitan soal dengan nilai yang berbobot 1-7.

Teknik pengumpulan data ada tiga yaitu: 1) tes adalah alat yang digunakan untuk menilai kemampuan individu berdasarkan jawaban yang diberikan oleh siswa, memungkinkan untuk ditentukan sejauh mana kemampuannya. Tes yang digunakan adalah tes uraian. 2) Dokumentasi untuk melengkapi hasil yang telah dicapai dan mendapatkan data jumlah siswa serta RPP kelas XI IPA SMA Muhammadiyah Pangsid dan tempat penelitian. 3) Kuesioner merupakan teknik untuk memperoleh data dengan memberikan daftar pertanyaan atau pertanyaan tertulis yang ditanggapi atau dijawab oleh sejumlah responden juga digunakan untuk memperoleh informasi dengan valid.

Metodologi analisis data yang digunakan dalam penelitian ini adalah teknik statistik desriptif. Adapun rumus yang digunakan dalam pengolahan data adalah sebagai berikut. 1) Pemberian skor, Penilaian kepada siswa dilakukan dengan menjumlahkan skor yang diperoleh dari setiap bagian pembelajaran dibagi skor total, kemudian dikalihkan dengan 100. Adapun skor total yaitu 39 dari nomor 1-10, rumus yang digunakan adalah.

$$
N=\frac{\text { Skor Perolehan }}{\text { Skor Maksimal }} \times 100 \%
$$

2) Rumus persentase, Teknik statistik deskriptif digunakan untuk menganalisis data dalam penelitian ini. Kriteria kemampuan yang ditetapkan $85 \%$ dengan nilai ketuntasan minimal 70 pada skala penilaian 10-100. Adapun rumus yang digunakan dalam pengolahan data adalah sebagai berikut:

$$
\begin{aligned}
& \mathrm{P}=\frac{F}{N} \times 100 \% \\
& \text { Keterangan: } \\
& \mathrm{P}=\text { Persentase } \\
& \mathrm{F}=\text { Frekuensi siswa yang mendapat nilai } 70 \text { ke atas } \\
& \mathrm{N}=\text { Banyaknya siswa sampel. }
\end{aligned}
$$


Usman, M. (2021). Efektivitas Penggunaan Google Classroom pada Masa Pandemi Covid-19 terhadap Hasil Belajar Pendidikan Kewarganegaraan. Edudikara: Jurnal Pendidikan dan Pembelajaran, 6(3), 199210.

\section{HASIL PENELITIAN}

Penelitian ini dilaksanakan di SMA Muhammadiyah Pangsid yang berlokasi di Jl. Ganggawa No. 151, Kelurahan Majjelling, Kecamatan Maritengngae, Kabupaten Sidenreng Rappang, Sulawesi Selatan. Penelitian ini berlangsung pada tanggal 19 Maret 2021 sampai dengan tanggal 19 Mei 2021. Data yang diperoleh dalam penelitian ini berupa data yang terkumpul dari tes hasil belajar PKn yang diberikan kepada siswa kelas XI IPA berupa pretest dan posttest yang dilakukan pada satu kelas, dalam pembelajaran menggunakan media Google Classroom pada kelas XI IPA sebanyak 13 siswa.

Berdasarkan kriteria Menurut Slavin dalam (Afriliani, 2019), ada 4 indikator yang dapat digunakan untuk mengukur keefektifan pembelajaran yaitu; 1) Analisis kualitas pembelajaran. Deskripsi data hasil penelitian pretest posttest (menggunakan Google Classroom ) dapat dilihat pada uraian prestasi belajar siswa kelas XI IPA. Data dalam penelitian ini diperoleh dari hasil pengukuran pretest dan posttest. Hasil pengukuran menunjukkan adanya peningkatan prestasi belajar pada mata pelajaran PKn mengenai faktor pendorong dan penghambat persatuan dan kesatuan bangsa.

Tabel 4 Skor Perolehan dan Nilai Pretest Postest Hasil Belajar Siswa

\begin{tabular}{|c|c|c|c|c|}
\hline \multirow[t]{2}{*}{ No. } & \multicolumn{2}{|c|}{ Pretest } & \multicolumn{2}{|c|}{ Postest } \\
\hline & Skor Perolehan & Nilai & Skor Perolehan & Nilai \\
\hline 1. & 22 & 57 & 31 & 80 \\
\hline 2. & 27 & 70 & 33 & 85 \\
\hline 3. & 29 & 75 & 35 & 90 \\
\hline 4. & 17 & 44 & 28 & 72 \\
\hline 5. & 29 & 75 & 37 & 95 \\
\hline 6. & 27 & 70 & 31 & 80 \\
\hline 7. & 22 & 57 & 29 & 75 \\
\hline 8. & 18 & 46 & 28 & 72 \\
\hline 9. & 27 & 70 & 35 & 90 \\
\hline 10. & 17 & 44 & 26 & 67 \\
\hline 11. & 19 & 49 & 29 & 75 \\
\hline 12. & 22 & 57 & 28 & 72 \\
\hline 13. & 24 & 62 & 31 & 80 \\
\hline & Jumlah & 776 & & 1033 \\
\hline & Mean & 60 & & 80 \\
\hline & Max & 75 & & 95 \\
\hline & Min & 44 & & 67 \\
\hline & Stedev & 11.57 & & 8.45 \\
\hline & Ket. & & & \\
\hline
\end{tabular}

1) Pretest

Tabel 5 Distribusi Frekuensi Nilai Hasil Belajar Pretest

\begin{tabular}{cccccc}
\hline Kelas & $\begin{array}{c}\text { Jumlah } \\
\text { Siswa }\end{array}$ & $\begin{array}{c}\text { Nilai } \\
\text { Max }\end{array}$ & Nilai Min & $\begin{array}{c}\text { Standar } \\
\text { Deviasi }\end{array}$ & Nilai Mean \\
\hline XI IPA & 13 & 75 & 44 & 11.57 & 60 \\
\hline
\end{tabular}

Pretest dilakukan untuk mengetahui sejauhmana pengetahuan siswa mengenai faktor pendorong dan penghambat persatuan dan kesatuan bangsa yang diajarkan, sebelum siswa 
Usman, M. (2021). Efektivitas Penggunaan Google Classroom pada Masa Pandemi Covid-19 terhadap Hasil Belajar Pendidikan Kewarganegaraan. Edudikara: Jurnal Pendidikan dan Pembelajaran, 6(3), 199210.

mendapat perlakuan atau sebelum pembelajaran. Data yang terkumpul pada saat pretest diperoleh maksimum sebesar 75; minimum 44; standar deviasi 11.57 dan mean 60

2) Posttest

Tabel 6 Distribusi Frekuensi Nilai Hasil Belajar Posttest

\begin{tabular}{cccccc}
\hline Kelas & $\begin{array}{c}\text { Jumlah } \\
\text { Siswa }\end{array}$ & $\begin{array}{c}\text { Nilai } \\
\text { Max }\end{array}$ & $\begin{array}{c}\text { Nilai } \\
\text { Min }\end{array}$ & $\begin{array}{c}\text { Standar } \\
\text { Deviasi }\end{array}$ & Nilai Mean \\
\hline XI IPA & 13 & 95 & 67 & 8.45 & 80 \\
\hline
\end{tabular}

Posttest dilakukan setelah proses belajar mengajar untuk mengetahui untuk mengetahui sejauhmana pengetahuan siswa mengenai faktor pendorong dan penghambat persatuan dan kesatuan bangsa yang diajarkan. Data hasil penelitian pada posttest adalah maksimum 95; minimum 67; standar deviasi 8.45 dan mean 80.

Berdasarkan pada tabel 4.2 dan 4.3 diatas dapat dilihat pretest dan posttest mengalami peningkatan. Hal tersebut ditandai adanya perubahan nilai rata-rata yang signifikan.

Berdasarkan tabel 4.2 dan 4.3 , selanjutnya dilihat perbandingan pada tabel 4.4 berikut ini.

Tabel 7 Hasil Perbandingan Pretest dan posttest

\begin{tabular}{ccccc}
\hline No. & Tes & Simpangan baku & Average & Mean \\
\hline 1. & Pretest & 11.57 & 734 & 60 \\
2. & posttest & 8.45 & 1033 & 80 \\
\hline
\end{tabular}

Hasil analisa data pada tabel 4.3 diatas dapat dilihat pretest dan posttest mengalami peningkatan. Hal tersebut ditandai adanya perubahan nilai rata-rata yang signifikan. Berdasarkan hasil uji analisis deskriptif tersebut menunjukkan $80>60$, sehingga dapat dikatakan bahwa terdapat perbedaan signifikan antara hasil belajar siswa.

Analisis tingkat kesesuaian yaitu sejauh mana guru memastikan bahwa siswa sudah siap untuk mempelajari suatu pembelajaran baru atau menerima materi baru. Hasil tes siswa yang tertera dalam tabel 4.5 diperoleh nilai rata-rata siswa sebagai berikut: 
Usman, M. (2021). Efektivitas Penggunaan Google Classroom pada Masa Pandemi Covid-19 terhadap Hasil Belajar Pendidikan Kewarganegaraan. Edudikara: Jurnal Pendidikan dan Pembelajaran, 6(3), 199210.

Tabel 4.5 Frekuensi dan Nilai Siswa Setelah Mendapat Perlakuan

\begin{tabular}{cccc}
\hline No & NILAI & FREKUENSI & JUMLAH \\
\hline $\mathbf{1}$ & 50 & - & - \\
$\mathbf{2}$ & 60 & - & - \\
$\mathbf{3}$ & 67 & 1 & 67 \\
$\mathbf{4}$ & 72 & 3 & 216 \\
$\mathbf{5}$ & 75 & 2 & 150 \\
$\mathbf{6}$ & 80 & 3 & 240 \\
$\mathbf{7}$ & 85 & 1 & 85 \\
$\mathbf{8}$ & 90 & 2 & 180 \\
$\mathbf{9}$ & 95 & 1 & 95 \\
& JUMLAH & 13 & 1033 \\
& RATA-RATA & & 80 \\
\hline
\end{tabular}

Berdasarkan Tabel 4.5 nilai rata-rata yang diperoleh siswa yaitu 80 dan jumlah 1033. Untuk mengetahui kriteria ketuntasan belajar siswa maka diuraikan nilai diatas menggunakan rumus pengolahan data sebagai berikut;

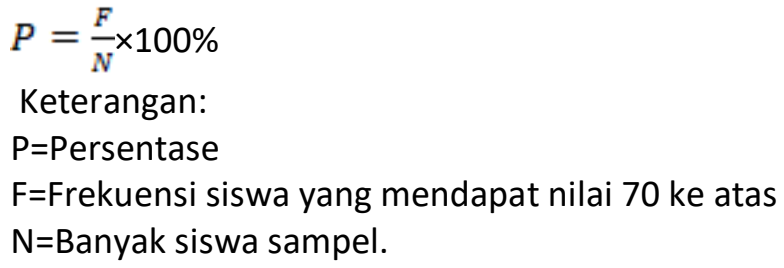

Maka,

$$
\begin{aligned}
P & =\frac{12}{13} \times 100 \% \\
& =92,3 \%
\end{aligned}
$$

Tindakan insentif. Intensif, didefinisikan sebagai sejauh mana guru memastikan bahwa siswa termotivasi bekerja untuk menyelesaikan tugas yang telah diberikan dan untuk belajar tentang materi yang telah disampaikan melalui Google Classroom. Untuk mengukur minat dalam penerapan pembelajaran dengan menggunakan media Google Classroom beberapa teknik yang biasa digunakan salah satunya memberikan kuesioner kepada siswa.

\begin{tabular}{|c|c|c|c|c|c|c|}
\hline \multirow[t]{2}{*}{ Faktor } & \multirow[t]{2}{*}{ No. } & \multirow[t]{2}{*}{ Pertanyaan } & \multicolumn{4}{|c|}{ Penilaian } \\
\hline & & & STS & TS & $\mathrm{S}$ & SS \\
\hline \multirow[t]{2}{*}{$\begin{array}{c}\text { Keberhasilan } \\
\text { pembelajaran } \\
\text { menggunakan } \\
\text { Google } \\
\text { Classroom }\end{array}$} & 1. & $\begin{array}{l}\text { Google Classroom dapat } \\
\text { menggantikan pertemuan } \\
\text { langsung pada saat proses } \\
\text { pembelajaran } \\
\text { ? }\end{array}$ & 0 & 0 & 33 & 0 \\
\hline & 2. & $\begin{array}{l}\text { Google Classroom } \\
\text { memudahkan saya dalam } \\
\text { memahami } \quad \text { materi }\end{array}$ & 0 & 2 & 30 & 0 \\
\hline
\end{tabular}

\section{DAFTAR QUISIONER}


Usman, M. (2021). Efektivitas Penggunaan Google Classroom pada Masa Pandemi Covid-19 terhadap Hasil Belajar Pendidikan Kewarganegaraan. Edudikara: Jurnal Pendidikan dan Pembelajaran, 6(3), 199210.

\begin{tabular}{|c|c|c|c|c|c|c|}
\hline & & $\begin{array}{l}\text { pembelajaran } \\
\text { ? }\end{array}$ & & & & \\
\hline & 3. & $\begin{array}{l}\text { Google Classroom } \\
\text { memudahkan saya dalam } \\
\text { memperoleh } \\
\text { pengumuman, materi dan } \\
\text { pengumpulan tugas } \\
\text { ? }\end{array}$ & 0 & 0 & 15 & 24 \\
\hline \multirow[t]{5}{*}{$\begin{array}{c}\text { Kemudahan } \\
\text { menggunakan } \\
\text { Google } \\
\text { Classroom }\end{array}$} & 4. & $\begin{array}{l}\text { Tampilan Google } \\
\text { Classroom sangat jelas dan } \\
\text { mudah dipahami } \\
?\end{array}$ & 0 & 0 & 27 & 8 \\
\hline & 5. & $\begin{array}{ll}\text { Menu pada } & \text { Google } \\
\text { Classroom } & \text { mudah } \\
\text { digunakan?? } & \end{array}$ & 0 & 0 & 15 & 24 \\
\hline & 6. & $\begin{array}{l}\text { Penggunaan } \\
\text { Classroom } \\
\text { dipelajari } \\
?\end{array}$ & 0 & 6 & 18 & 8 \\
\hline & 7. & $\begin{array}{l}\text { Google Classroom mudah } \\
\text { diakses } \\
\text { ? }\end{array}$ & 0 & 8 & 18 & 4 \\
\hline & 8. & $\begin{array}{l}\text { 1. Google Classroom } \\
\text { mempercepat dalam } \\
\text { pengumpulan tugas } \\
\text { ? }\end{array}$ & 0 & 0 & 15 & 24 \\
\hline
\end{tabular}

\begin{tabular}{|c|c|c|c|c|c|c|}
\hline \multirow[t]{4}{*}{$\begin{array}{c}\text { Kendala } \\
\text { pembelajaran } \\
\text { menggunakan } \\
\text { Google } \\
\text { Classroom }\end{array}$} & 9. & $\begin{array}{l}\text { Kuota dan Jaringan internet } \\
\text { menjadi penghambat saya } \\
\text { dalam pembelajaran daring } \\
\text { menggunakan Google } \\
\text { Classroom } \\
\text { ? }\end{array}$ & 0 & 0 & 15 & 24 \\
\hline & 10. & $\begin{array}{l}\text { Listrik menjadi penghambat } \\
\text { saya dalam pembelajaran } \\
\text { daring menggunakan Google } \\
\text { Classroom } \\
\text { ? }\end{array}$ & 2 & 4 & 12 & 12 \\
\hline & 11. & $\begin{array}{l}\text { Perangkat yang saya miliki } \\
\text { menjadi penghambat dalam } \\
\text { mengakses } \\
\text { Classroom. }\end{array}$ & 2 & 6 & 15 & 8 \\
\hline & & Jumlah & 4 & 26 & 213 & 136 \\
\hline
\end{tabular}


Usman, M. (2021). Efektivitas Penggunaan Google Classroom pada Masa Pandemi Covid-19 terhadap Hasil Belajar Pendidikan Kewarganegaraan. Edudikara: Jurnal Pendidikan dan Pembelajaran, 6(3), 199210.

Waktu, yaitu siswa dapat menyelesaikan pembelajaran sesuai dengan alokasi waktu yang dijadwalkan. Adapun waktu yang digunakan yaitu 60 menit dengan pertemuan $1 \times 3$ minggu, 5 menit digunakan untuk menyapa siswa, 10 menit digunakan untuk mengabsen, 45 menit digunakan untuk belajar. Adapun waktu untuk mengerjakan tugas diberikan cukup lama yaitu batas pengumpulan tugas yang diberikan yaitu sampai pada pertemuan berikutnya.

\section{PEMBAHASAN}

Siswa dapat belajar dari jarak jauh atau di ruang kelas dengan pembelajaran berbasis Google Classroom ini. Proses belajar juga dapat berlangsung setiap saat dan tanpa memperhatikan waktu, sehingga memungkinkan siswa untuk belajar dengan kecepatannya sendiri. Dalam hal ini peran guru yang biasanya dalam pembelajaran di kelas sebagai pemberi materi akan digantikan dengan Google Classroom yang telah siap dengan simulasi materi yang akan dipelajari. Sehingga siswa yang kurang paham dapat mempelajarinya dimanapun dan kapanpun.

Pembelajaran yang dilakukan sistem pretest dan posttest peneliti membuat kelas di Classroom khusus untuk mata pelajaran PKn kelas XI IPA. Peneliti mmembagikan kode Classroom melalui grup WA agar siswa bergabung untuk melihat materi dan tugas yang sudah disiapkan. Adapun tugas diberikan yang terdiri dari 10 nomor uraian dengan bobot yang berbeda sesuai dengan tingkat kesulitan soal yaitu 1-7 dan skor maksimal 39. Adapun batas pengumpulan tugas yang diberikan yaitu sampai pada pertemuan berikutnya. Mengapa diberikan waktu lama supaya semua siswa diharapkan mengirim tugasnya.

Berdasarkan hasil penelitian dengan menggunakan Google Classroom tes pretest dan posttest diperoleh nilai rata-rata berbeda. Pada uji awal sebelum diberikan perlakuan siswa kelas XI IPA hanya lima siswa yang tuntas yang lainnya tidak tuntas berdasarkan kriteria ketuntasan minimal (KKM) yang ditentukan oleh pihak sekolah yaitu 70. Namun, setelah diberikan perlakuan pembelajaran melalui Google Classroom terjadi peningkatan dari 13 peserta yang diikutsertakan dalam penelitian ini, 12 siswa dinyatakan tuntas, tetapi 1 siswa dinyatakan tidak tuntas. Berdasarkan kriteria Menurut Slavin dalam (Afriliani, 2019), ada 4 indikator yang dapat digunakan untuk mengukur keefektifan pembelajaran yaitu; 1) kualitas pembelajaran, dapat diketahui dari besarnya kadar informasi yang disajikan oleh guru kepada siswa agar siswa dengan mudah menangkap materi. Dalam hasil uji dapat dijadikan ketuntasan belajar siswa dapat dilihat dari selisih antara hasil posttest dengan pretest. Ketercapaian belajar siswa dapat dilihat bahwa setiap siswa mengalami peningkatan. Dapat disimpulkan bahwa tingkat kesalahan yang dilakukan oleh guru sangat kecil, selain itu adanya ketercapaian penguasaan tujuan pembelajaran yang didapatkan dari selisih pretest dan posttest sehingga proses pembelajaran dapat dikatakan efektif. 2) Tingkat pembelajaran yang sesuai, didefinisikan sejauh mana guru memastikan bahwa siswa siap untuk mempelajari pelajaran baru atau menerima materi baru, efektivitas belajar seberapa besar tingkat informasi yang disajikan sehingga siswa dapat dengan mudah mempelajarinya atau tingkat kesalahannya semakin kecil. Dalam pengamatan penelitian ini, bahwa pemilihan materi dan media Google Classroom yang digunakan disesuaikan dengan kemampuan siswa dalam menangkap pelajaran sehingga mudah dipahami karena materi yang disampaikan melalui media Google Classrom dirasakan sangat mudah ditangkap oleh siswa. Hal ini dilihat dari persentase ketuntasan belajar siswa.

3) Intensif, didefinisikan sebagai sejauh mana guru memastikan bahwa siswa termotivasi bekerja untuk menyelesaikan tugas. yang telah diberikan dan untuk belajar tentang materi yang telah disampaikan. Besarnya usaha yang dilakukan guru untuk memotivasi siswa belajar agar tercipta suasana yang antusias dan menyenangkan menentukan pembelajaran. Sebelum siswa diberikan tugas peneliti terlebih dahulu membuat tutorial cara mengirim tugas. Selama penelitian ini berlangsung, penulis melihat bahwa menggunakan media Google Classroom 
Usman, M. (2021). Efektivitas Penggunaan Google Classroom pada Masa Pandemi Covid-19 terhadap Hasil Belajar Pendidikan Kewarganegaraan. Edudikara: Jurnal Pendidikan dan Pembelajaran, 6(3), 199210.

sebagai media pembelajaran berhasil membuat siswa merasa antusias senang dengan kegiatan belajar yang berlangsung. Berdasarkan kuesioner respon siswa tentang Google Classroom memudahkan dalam memperoleh pengumuman materi dan pengumpulan tugas. 4) Waktu, yaitu siswa dapat menyelesaikan pembelajaran sesuai dengan alokasi waktu yang dijadwalkan. Untuk itu peneliti dapat menyimpulkan bahwa salah satu indikator ini tuntas karena siswa menyelesaikan tugas dengan waktu yang telah ditentukan yaitu batas pengumpulan sebelum pertemuan berikutnya.

Dari keempat indikator dalam menentukan efektivitas pembelajaran menurut Slavin dalam (Afriliani, 2019), empat indikator tersebut telah dikemukakan, dilaksanakan dan dicapai dalam penelitian, sehingga pembelajaran menggunakan Google Classroom dikatakan efektif pada materi PKn kelas XI IPA.

Adapun kendala yang didapatkan dalam pembelajaran daring adalah kuota dan jaringan internet. Hal ini dapat dilihat dari tanggapan responden tentang kuota dan Jaringan internet menjadi penghambat dalam pembelajaran daring menggunakan Google Classsroom dengan $57,1 \%$ yang mengatakan sangat setuju dan $42,9 \%$ yang menjawab setuju.

\section{SIMPULAN DAN SARAN}

Berdasarkan hasil analisis data dan pembahasan disimpulkan bahwa penggunaan Google Classroom efektif di masa pandemi Covid-19 terhadap hasil belajar PKn siswa kelas XI IPA SMA Muhammadiyah Pangsid. Hal ini dibuktikan dengan pada hasil analisis data yang menunjukkan bahwa dari 4 (empat) indikator efektivitas menurut Slavin dalam (Afriliani, 2019) semuanya memenuhi syarat yaitu : 1) Ketercapaian belajar siswa dapat dilihat bahwa setiap siswa mengalami peningkatan dengan nilai mean posttest lebih tinggi yaitu 80 sedangkan hasil pretest yaitu 60. 2) Adanya kesesuaian materi ajar dengan kemampuan siswa dilihat dari persentase keseluruhan siswa yang memenuhi standar KKM yaitu 92,3\%. 3) Terbangunnya motivasi belajar siswa selama mengikuti pembelajaran dapat dilihat dari hasil kuesioner. 4) Siswa dapat menyelesaikan pembelajaran sesuai dengan alokasi waktu yang dijadwalkan.

Berdasarkan ke empat indikator tersebut semua terpenuhi, maka hipotesis kerja atau hipotesis alternatif bahwa : "penggunaan media Google Classroom efektif terhadap hasil belajar PKn siswa kelas XI IPA SMA Muhammadiyah Pangsid Tahun Pelajaran 2021", diterima. Sedangkan hipotesis nol atau nihil yang menyatakan bahwa : "penggunaan media Google Classroom tidak efektif terhadap hasil belajar PKn siswa kelas XI IPA SMA Muhammadiyah Pangsid Tahun Pelajaran 2021", ditolak.

Berdasarkan hasil penelitian yang telah dilakukan dengan judul efektivitas Google Classroom di masa pandemi Covid-19 terhadap hasil belajar PKn siswa kelas XI IPA SMA Muhamadiyah Pangsid, maka peneliti menyarankan sebagai berikut: 1) Pihak sekolah hendaknya memberikan dukungan pada pengembangan metode pembelajaran berbasis aplikasi Google Classroom. 2) Bagi peserta didik sebaiknya bisa menyimpan data pembelajaran yang diberikan oleh guru melalui aplikasi Google Classroom sehingga bisa dipelajari dimanapun dan kapanpun. 3) Bagi pembaca, skripsi ini dapat dijadikan referensi untuk mengadakan penelitian lebih lanjut dengan populasi dan sampel yang berbeda guna memperkuat keberhasilan aplikasi Google Classroom terhadap hasil belajar dan keaktifan peserta didik, atau pada faktor lain 
Usman, M. (2021). Efektivitas Penggunaan Google Classroom pada Masa Pandemi Covid-19 terhadap Hasil Belajar Pendidikan Kewarganegaraan. Edudikara: Jurnal Pendidikan dan Pembelajaran, 6(3), 199210.

\section{REFERENSI}

Sugiyono, Prof. Dr. 2016. "Metode Penelitian Manajemen Pendekatan Kuantitatif, Kualitatif, Kombinasi (Mixed Method), Penelitian Tindakan (Action Resears) dan Penelitian Evaluasi." Bandung: Alfa Beta(1-108).

Afrianti, Wahyuni Eka. 2018. "Penerapan Google Classroom dalam Pembelajaran Akutansi." 1-122.

Afriliani, Nurish Shabacha. 2019. "Efektivitas Pendekatan Realistic Mathematic Education (RME) pada Materi Pokok Uang Peserta Didik Kelas IV SD Negeri Soko." Journal of Chemical Information and Modeling 53(9):1689-99.

Andriyani, Ufi Nurul. 2016. "Penerapan Model Pembelajaran Examples Non Examples dalam Meningkatkan Hasil Belajar Siswa Kelas IV pada Mata Pelajaran Pendidikan Kewarganegaraan (PKn) di Madrasah Ibtidaiyah Nurussalam Sidogede Kecamatan Belitang Kabupaten Oku Timur."

Aulia, Dewi. 2019. "Implementasi Penggunaan Media Display Classroom dalam Pembelajaran Geografi Materi Pokok Penginderaan Jauh Kelas X II SMA Negeri 2 Kota Semarang Tahun Pelajaran 2018/2019."

Dr. Usiono, MA. 2017. “Jurnal Pancasila dan Kewarganegaraan.” Journal 2(1):23-33.

Famukhit, M. L. 2020. "Google Classroom Sebagai Media Pembelajaran Daring Online pada Program Studi Pendidikan Informatika SKIP PGRI Pacitan." Jurnal Penelitian Pendidikan.

Iftakhar, Shampa. 2016. "Google Classroom: What Works and How?" 3:12-18.

Nurgiansah, T. Heru. 2019. "Pemutakhiran Kurikulum Pendidikan Kewarganegaraan di Era Revolusi Industri 4.0." Prosiding Seminar Kewarganegaraan Universitas Negeri Medan 1(1):95-102.

S., SUPARDI U. 2015. "Hasil Belajar Matematika Siswa Ditinjau dari Interaksi Tes Formatif Uraian dan Kecerdasan Emosional." Formatif: Jurnal IImiah Pendidikan MIPA 3(2):78-96.

Sirojuddin, Abud. 2020. "Pengaruh Pembelajaran Blended Learning Menggunakan Aplikasi Google Classroom di Masa Pandemi Covid 19 terhadap Kemampuan Komunikasi Matematis Siswa Sekolah Menengah Pertama Negeri 7 Muaro Jambi." 2507(1):1-9.

UU RI, NO.20, 2003, Pasal. .. 2003. “Undang-Undang Republik Indonesia Nomor 20 Tahun 2003 Tentang Sistem Pendidikan Nasional." 60(1):147-73.

Wicaksono, Lucky Eko Prasetyo. 2018. “Efektivitas Pemanfaatan Media Power Point dan Media Poster dalam Meningkatkan Hasil Belajar pada Mata Pelajaran Akidah Akhlak Kelas 8 SMP Muhammadiyah 1 Mlati." 2:227-49.

Wiguna, Sonalita. 2018. "Efektivitas Learning Management System Edmodo Berbasis Smartphone pada Hasil Belajar Siswa."

Durahman, Durahman. 2020. "Pemanfaatan Google Classroom sebagai Multimedia Pembelajaran bagi Guru Madrasah pada Diklat di Wilayah Kerja Kemenag Kabupaten Cianjur." Tatar Pasundan : Jurnal Diklat Keagamaan 12(34):215-21.

Syahmina, Ifrah. 2020. "Efektivitas Pembelajaran Biologi pada Masa Pandemi Covid-19 di Madrasah Aliyah Negeri 1 Medan ." 2507(1):1-9.

Ferniawan. 2020. "Efektifitas Penggunaan Media Poster 3 Dimensi Secara Daring pada Materi Tata Surya Berbasis Google Classroom untuk Meningkatkan Pemahaman Konsep Fisika Siswa Kelas VII SMPN 1 Wera Tahun Pelajaran 2019/2020 Skripsi." 2507(1):1-9.

Fahimi, Ahmad. 2019. "Efektifitas Pembelajaran E-Learning Melalui Google Classroom pada Madrasah Ibtida'iyah di Kabupaten Rembang."

Hisyam Surya, Euis Ismayati, Achmad Imam, Tri Rijianto. 2020. "Media E-Learning Berbasis Google Classroom untuk Meningkatkan Hasil Belajar Siswa SMK." 09 (3).

Damayanti, Herry Novis and Sutama. 2016. "Efektivitas Flipped Classroom terhadap Sikap dan Ketrampilan Belajar Matematika di SMK." Manajemen Pendidikan 11(1):2.

Fedistia, Ridia And Edwin Musdi. 2020. "Efektivitas Perangkat Pembelajaran Berbasis Flipped Classroom untuk Meningkatkan Kemampuan Penalaran Matematis Peserta Didik." Jurnal Didaktik Matematika 7(1):45-59.

Arruji, Edo. 2020. "Pengaruh Media Google Classroom terhadap Hasil Belajar pada Konsep Sistem Gerak."

Suryacitra, Gabriella Elsa. 2018. "Efektivitas Penerapan Model Pembelajaran Flipped Classroom di Kelas X MIPA SMA N 1 Karanganom Tahun Ajaran 2017/2018 pada Materi Vektor." 
Usman, M. (2021). Efektivitas Penggunaan Google Classroom pada Masa Pandemi Covid-19 terhadap Hasil Belajar Pendidikan Kewarganegaraan. Edudikara: Jurnal Pendidikan dan Pembelajaran, 6(3), 199210.

Hammi, Zedha. 2017. "'Implementasi Google Classroom pada Kelas XI IPA MAN 2 Kudus.'” Skripsi 1-58. Sasongko \& Harimurti, Rina. 2019. "Penerapan Self-Diirected Learning Berbasis Google Classroom untuk Meningkatkan Hasil Belajar di SMK Negeri 2 Surabaya." It-Edu 04(1):96-103.

Afriliani, Nurish Shabacha. 2019. "Efektivitas Pendekatan Realistic Mathematic Education (RME) pada Materi Pokok Uang Peserta Didik Kelas IV SD Negeri Soko." Journal Of Chemical Information And Modeling 53(9):1689-99.

Sari, Ega Puspita. 2015. "Penggunaan Media Komik dalam Pembelajaran PKn Untuk Membina Karakter Kewarganegaraan." 1-8.

Hidayah, N. and M. Sondang Sumbawati. 2019. "Efektivitas Model Pembelajaran Flipped Classroom terhadap Self Regulated Learning dan Hasil Belajar Siswa pada Mata Pelajaran Dasar Desain Grafis di SMK N 1 Surabaya." It-Edu 04(01):165-73.

Putri, A. N., Pd, M. E., \& Pd, M. E. (2020). Efektivitas Pembelajaran Daring Program Studi Pendidikan Ekonomi. 3(4), 627-634. 